SECTION 19. Management. Marketing. Public administration.

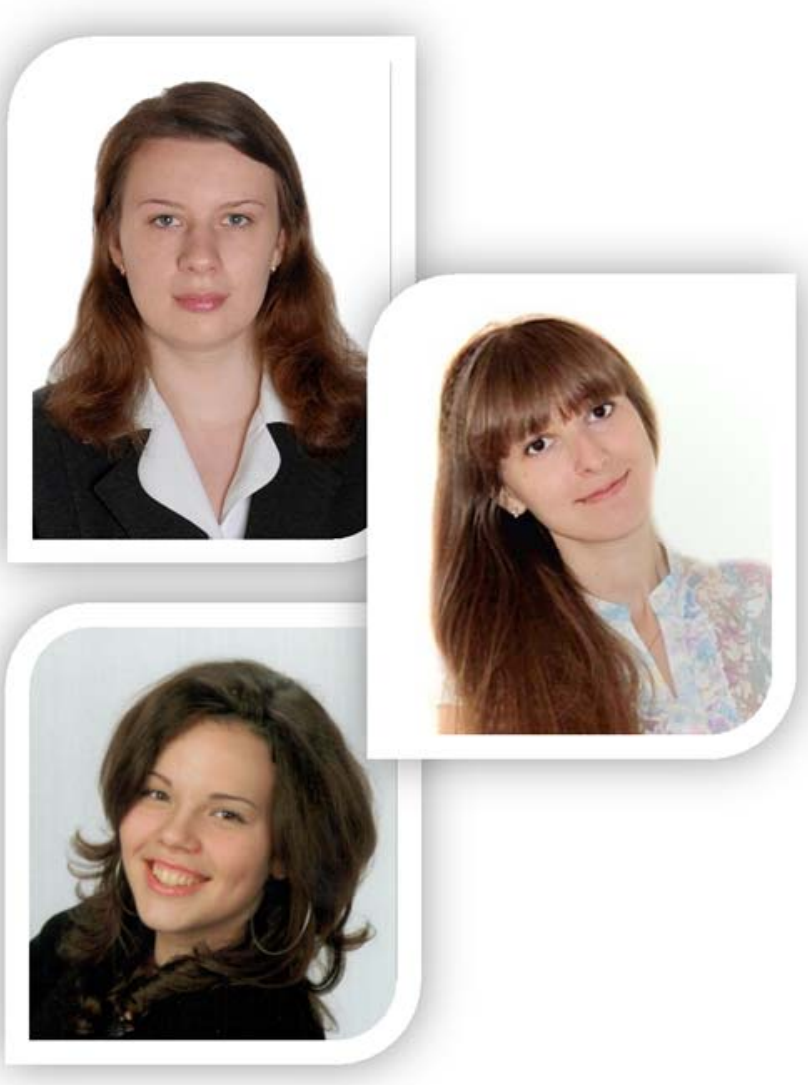

\begin{abstract}
Marina Konstantinovna Krivtsova
the third year student, bachelor, the Chairman of Scientific Student Society of the faculty of Public and municipal administration at the Financial University under the Government of the Russian Federation marinstar@bk.ru

Elena Sergeevna Sviridova the third year student, bachelor, the Deputy Chairman of Scientific Student Society in the field of information policy of the faculty of

Public and municipal administration at the Financial University under the Government of the Russian Federation

Daria Evgenievna Petrova the student of the faculty of International economic relations at the Financial University under the Government of the Russian Federation
\end{abstract}

\title{
THE INTERNATIONAL EXPERIENCE OF MAINTAINING SERVICE AND PROFESSIONAL ETHICS PUBLIC SERVICE
}

\begin{abstract}
In this article the main aspects of international practice in the field of maintenaning service and professional ethics in public service are considered. Special attention is paid to the requirements of the ethics of service behavior as well as strict implementation of these rules. The article describes a required set of ethical qualities whichevery official should have. In conclusion the findings regarding moral regulation of public service are presented.

Key words: The ethics of public service, government bodies, citizens, the institute of oath, code, administrative punishment, stimulation, reform, moral values, the mode of administrative prohibitions, legislation, confidential information.
\end{abstract}

УДК 351

\section{ЗАРУБЕЖНЫЙ ОПЫТ ПОДДЕРЖАНИЯ СЛУЖЕБНОЙ И ПРОФЕССИОНАЛЬНОЙ ЭТИКИ НА ГОСУДАРСТВЕННОЙ СЛУЖБЕ}

Аннотация: В статье рассматриваются основные аспекты зарубежной практики в области поддержания служебной и профессиональной этики на государственной службе. Отдельное внимание уделяется повышению требований к этичности служебного поведения, а также неукоснительное исполнение данных правил. В работе описывается необходимый набор этических качеств, которыми должен обладать чиновник. В заключении приведены выводы, касающиеся нравственного регулирования государственной службы. 
Ключевые слова: Этика государственной службы, государственные органы, граждане, институт присяги, кодекс, административное наказание, стимулирование, реформа, нравственные ценности, режим административных запретов, законодательство, конфиденциальная информация.

В мировой практике для обеспечения реализации этических принципов в деятельности государственных служащих используются и положительно себя зарекомендовали такие механизмы, как: этические кодексы; комитеты по этике; тренинг; социальные аудиты; специальные службы, рассматривающие факты нарушений сотрудниками организации этических требований, а также претензии граждан по этическим вопросам; институт присяги.

Большое значение для разработки теоретических оснований эффективного этического кодекса российского чиновника имеет западный и восточный опыт.

Кодексы этики созданы в ряде стран. Так, впервые в США Кодекс этики государственной службы был введен в 1958 г. в виде резолюции Конгресса и носил рекомендательный характер, однако стал основой для правовой регламентации деятельности государственных служащих. На его основе в 1978 г. был принят закон «Об этике служащих государственных органов».[3, c.90] Затем этот закон реформировался (1989 г. - закон «О реформе Закона об этике», приказ Президента США № 12731 «Принципы этики поведения должностных лиц и служащих государственного аппарата»).

С апреля 2000 г. в Японии действуют Закон об этике государственных служащих, а также этические правила государственного служащего и нормы административных наказаний за их нарушение.[7, с.71]

В 1998 г. Международная организация по экономическому сотрудничеству и развитию опубликовала «Рекомендации по совершенствованию этического поведения в государственной службе», которые содержали основные принципы этического поведения государственных служащих и меры по его стимулированию. В мае 2000 г. Комитетом министров Совета Европы был одобрен «Модельный кодекс поведения государственных служащих», рекомендованный в качестве образца при принятии европейскими странами кодексов поведения государственных служащих.[9, с.105]

Одной из основных тенденций реформирования государственной службы в государствах Запада (Великобритания, Франция и др.) и Азии (Япония, Южная Корея, Сингапур и др.), а также в Южно-Африканской Республике является повышение требований к этичности служебного поведения государственных служащих, а такой компонент государственного управления, как нравственные ценности и гибкость реагирования на нужды граждан, становится все более значимым .

По мнению многих исследователей, важнейшей целью их принятия являлось не только неукоснительное исполнение правил поведения (конкретных юридических и морально-этических требований) государственных служащих, но и желание «добиться полной убежденности каждого гражданина США в честности и искренности усилий федерального правительства».

Ценностный этический кодекс государственной службы Канады чётко предписывает, что государственные служащие обязаны не просто соблюдать законы, но и избегать подозрений в недостойном поведении.

В Кодексе государственной службы Великобритании установлено, что государственные служащие должны стремиться решать стоящие перед ними вопросы благожелательно, эффективно, своевременно, непредвзято и квалифицированно, а в Законе о федеральных чиновниках Германии установлено, что чиновник, в частности, должен иметь необходимые для административного работника черты характера. Таким образом, вполне можно считать, что корректность предполагает вежливое (соблюдение 
правил приличия), тактичное и толерантное (поведение с чувством меры, с соблюдением такта и выдержки), доброжелательное отношение гражданского служащего не только к гражданам, но и к руководителям, коллегам и подчиненным.

Комитет министров Совета Европы в Рекомендации от 11 мая 2000 года № R (2000) 10 «О кодексах поведения для государственных служащих» рекомендует правительствам государств-членов СЕ при соблюдении национального законодательства и принципов, регулирующих деятельность государственной администрации, содействовать принятию национальных кодексов поведения для государственных служащих, руководствуясь Модельным кодексом поведения для государственных служащих.[10, с.15]

Указанный кодекс распространяется на большинство государственных служащих. К государственным служащим согласно Рекомендации Комитета министров Совета Европы относится любое лицо, служащее в публичном органе. Положения Модельного кодекса применимы также в отношении любого лица, работающего в частной структуре, которая выполняет задачу оказания публичных коммунальных услуг.[4, с.90] Однако требования этого кодекса не распространяются на избранных публичных представителей, т.е. выборных должностных лиц, а также членов правительства и лиц, выполняющих судебные функции. Требования к поведению этих государственных служащих определяются законодательными актами, определяющими их правовой статус.

В США режим административных запретов на государственной службе определяется такими актами как: Принципы этического поведения правительственных чиновников и служащих от 17 октября 1990 г., Законом об этике в правительственных учреждениях 1978 г. [5, с.74]

В Великобритании режим административных запретов на государственной службе определяется таким актом как Статус гражданской службы, Кодекс условий службы и оплаты государственных чиновников, Общие принципы поведения государственных служащих. Английская государственная служба предполагает чрезвычайно жесткие ограничительные правила поведения гражданских служащих в политической сфере по сравнению с другими западными государствами - английский служащий самый «несвободный» среди своих французских, немецкий и американских коллег.

В ФРГ режим административных запретов на государственной службе определяется такими актами как Федеральный закон «О государственных служащих», Федеральным законом «О дисциплинарном режиме государственной службы», закон «О федеральных кадрах».

Во Франции режим административных запретов на государственной службе определяется «Генеральным статусом государственной службы» . Согласно законодательству о государственной службе Франции, чиновник не должен быть корыстным, он не может вести параллельно с государственной службой предпринимательскую деятельность. Данный запрет, оправдан здравым смыслом, имеет ряд исключений в рамках того, чтобы от этого не пострадала профессиональная деятельность чиновника. Так, научная, литературная или артистическая деятельность допустимы при условии, что они не носят доминирующего характера .

Резюмируя вышеизложенное, необходимо отметить, что законодательство США и Канады, регламентирующее порядок прохождения государственной службы, включает в себя Административные кодексы и этические нормы поведения не допускающие конфликта интересов на государственной службе, обеспечивающие надлежащее использование государственных ресурсов и требующие достижения самого высокого уровня профессионализма и честности среди сотрудников. В числе 
эффективных методов предупреждения и пресечения коррупции в системе государственной службы США и Канады является:[8, с.45]

наложение запретов или ограничений на участие должностных лиц в официальных мероприятиях, в отношении которых у этих лиц имеется существенная прямая или косвенная финансовая заинтересованность;

наложение запретов или ограничений на участие должностных лиц в мероприятиях, являющихся предметом финансовой заинтересованности со стороны физических или юридических лиц, с которыми эти должностные лица ведут переговоры о поступлении на работу;

- наложение ограничений на деятельность бывших государственных служащих, если они представляют частные или личные интересы, ходатайствуя перед правительственным ведомством или министерством, в котором они раньше работали, такие ограничения могут включать запрет на участие таких должностных лиц в делах, которые они раньше лично курировали, а также запрет на защиту ими частных интересов посредством неправомерного использования своего влияния на правительственное ведомство или министерство, в котором они раньше работали, равно как и на использование конфиденциальной информации или информации, получаемой в ходе исполнения официальных функций на предыдущей работе в органах государственной власти;

- $\quad$ наложение запретов и ограничений на получение подарков и других благ;

- установление ограничений на неправомерное использование государственного имущества и ресурсов в частных интересах и др .

Как мы можем видеть законодательство США и Канады, о государственной службе, содержит ряд норм, которые могут быть использованы в ходе реформирования государственной службы Российской Федерации, которое помимо всего прочего должно носить и антикоррупционный характер. [6, с.113]

Можно констатировать, что мировой практикой утверждается необходимость создания и внедрения не столько этических кодексов, сколько «этических режимов», так как отдельные нормы и правила поведения не решают проблему нравственного регулирования государственной службы. Этический режим, по мнению С. Вобленко, представляет собой «пакет» из трех компонентов:

1) Кодекс поведения (общие принципы, общие заявления о честности и неподкупности).

2) Формальные этические правила, конкретизирующие нормы кодекса поведения, особенно правила декларирования финансовой информации.

3) Специальный орган, отвечающий за применение этих правил на практике и консультирующий заинтересованные стороны по вопросам этического характера .

\section{References:}

1. Бутова Т.В., Кокин Н.А., Цихоцкий Ф.Н., Индарбаев А.А. Регулирование этики на государственной службе как форма борьбы с коррупцией. Международный научнопрактический конгресс "The genesis of genius", научно-периодическое профессиональное издание,- отд. ред.: г. Женева (Швейцария), г. Минск (Республика Беларусь), г. Одесса (Украина), г. Санкт-Петербург (Российская Федерация), 2014. - Т-1, 246 с.

2. Ирхин Ю.В. Значение формирования системы компетенций и мотиваций при подготовке государственных служащих в современных условиях // Вестник Поволжской академии государственной службы. - 2010. - № 2. - С. 7.

3. Малиновский А.А. Кодекс профессиональной этики: понятие и юридическое значение // Журнал российского права. - 2008. - № 4 (136). - С. 39. 
4. Пухова М.М., Куликова Е. Механизмы воздействия заинтересованных групп на принятие государственных решений // Система государственного и муниципального управления: проблемы и перспективы развития: Сборник научных статей. Ч.1 Государственное управление - М.: Издательство ООО «ПКЦ Альтекс», 2010

5. Рагулина Ю.В. Российская система образования: трудности перехода к экономике знаний // М.: Транспортное дело России, № 5, 2008

6. Ионова А.И. Этика и культура государственного управления. М. 2011.

7. Состояние и особенности государственной службы Российской Федерации финансово-экономического профиля. Уч. пособие /Под ред. А. М. Беляева, Е.Д. Богатырева и др. - М.: Финакадемия при Правительстве РФ, 2007.

8. Черепанов В.В. Основы государственной службы и кадровой политики. - М.: ЮНИТИ-ДАНА, 2011.

9. Шувалова Н.Н. Служебное поведение государственного гражданского служащего: Моральные основы. - Ростов-н/Д: Феникс, 2013

10. Любимов А.П. Принципы правовой этики государственных служащих // Представительная власть. 2013. № 2. 